\title{
Acute on chronic parotitis causing osteomyelitis and pathological fracture of the mandible
}

\author{
Kitty Guo, ${ }^{1,2}$ Anthony Greenstein, ${ }^{1}$ Shaukat Mahmood, ${ }^{3}$ Terence Lowe ${ }^{3}$
}

'Department of Maxillofacial Surgery, NHS Lothian, Livingston, UK

${ }^{2}$ Department of Medical Education, Keele University, Keele, UK

${ }^{3}$ Department of Maxillofacial Surgery, Aberdeen Royal Infirmary, Aberdeen, UK

\section{Correspondence to} Kitty Guo; kittygguo@gmail.com

Accepted 6 May 2020

\section{DESCRIPTION}

A 63-year-old woman was seen by the maxillofacial department regarding her 4-month history of symptoms of parotitis of the left parotid gland. The patient presented with erythema of the skin overlying the gland, pus discharge from the Stensen's duct and raised inflammatory markers. This episode of infection was an acute episode on a background of a chronically inflamed gland. An ultrasound was taken showing an abscess tracking from the left salivary gland and following this, a CT was indicated. A CT scan (figure 1) taken shows a fluid collection in the substance of the gland with calculi in the duct. The CT scan additionally shows a comminuted fracture of the left condyle and coronoid process of the mandible (figure 2).

The mandible and the parotid gland are both located within the parotid masseteric fascia. This close anatomical relationship within the same facial envelope allowed the abscess to erode the mandible resulting in a pathological fracture. A similar process is more commonly seen in chronic dental infections, where, in some cases, a chronic sinus is seen on the adjacent gingiva, where the abscess erodes through the alveolar bone.

The patient was admitted under general medicine and initially treated with 2 days of intravenous tazocin, followed by intravenous flucloxacillin and metronidazole, fluids and massage therapy to encourage drainage of pus. ${ }^{1}$ This was based on microbiological findings that showed gram-positive cocci. The patient opted to have the mandibular fracture

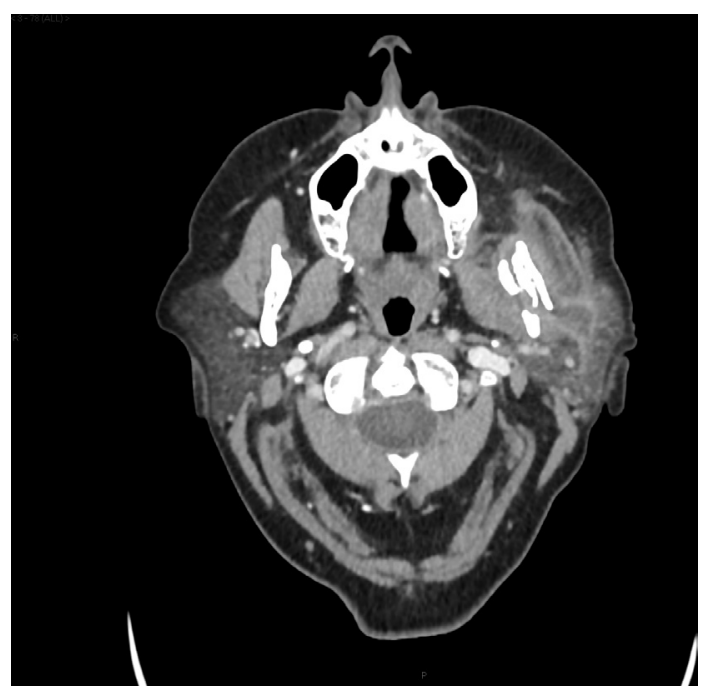

Figure 1 Axial CT slice soft tissue windowing showing a fluid collection in the left parotid gland with comminuted fracture visible.

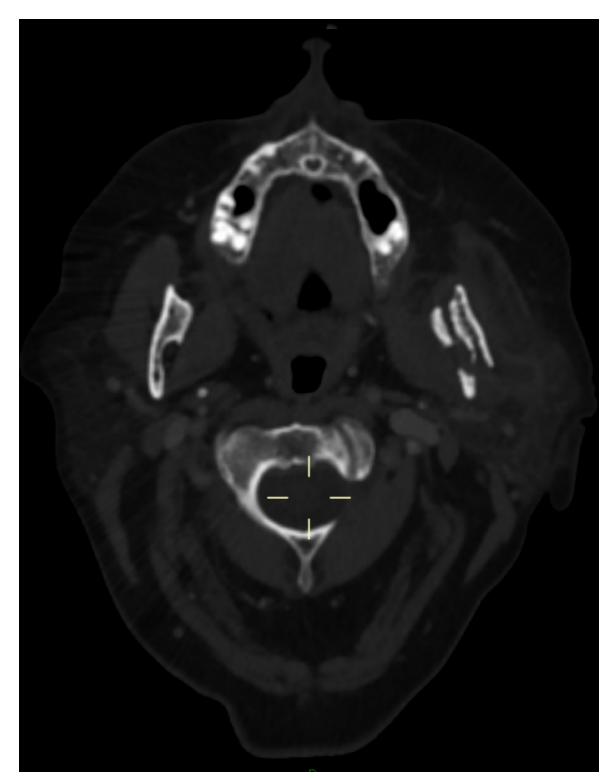

Figure 2 Axial CT slice bone windowing showing a comminuted fracture of the left mandible.

treated conservatively and has maintained satisfactory occlusion and function of her jaw. Sialadenitis associated with salivary stones requires removal of the stone if it does not spontaneously pass, which can be achieved through sialendoscopy if the stone is small enough to be passed through the parotid duct. Recurrent or persisting sialadenitis or larger stones may require surgical removal or partial removal of the gland. ${ }^{2}$ In this case, superficial parotidectomy was discussed with the patient to remove the calculus and chronically inflamed part of the parotid gland, but this was declined by the patient with risk of injury to the facial nerve, a significant factor contributing to her decision. The calculus was, therefore, left in this case, with follow-up of the patient every 4 months, or sooner should symptoms arise.

The patient had six follow-up appointments. Intraincisal opening remained within a normal

\section{Learning points}

Ultrasound scanning is the first line of imaging for sialadenitis; CT imaging may be indicated to rule out other pathologies.

- Osteomyelitis can be a rare complication of a parotid abscess, given the close proximity of the adjacent structures.

- Sialadenitis is usually managed with antibiotics, hydration and salivary stimulation. 
range between 35 and $45 \mathrm{~mm}$. Purulent discharge was still noted to be coming from the Stensen's duct on palpation, but she remained pain free and so declined further treatment. Although the pathological fracture was managed conservatively, her nutritional requirements and masticatory function were unimpaired. Fractured condyles of mandibles are commonly treated conservatively with minimal functional and occlusal derangement.

The patient was made aware of the high risk of recurrence of her symptoms and that surgical management may need to be reconsidered in the future, although significant comorbidities may preclude this.

Contributors AG conceived the idea and contributed to making amendments following review, approved the final version and agrees to be accountable for the article. KG reported the case and took the lead in writing the manuscript with input from all authors, approved the final version and agrees to be accountable for the article. SM and TL lead the treatment of the patient, contributed to revision of the article, approved the final version and agreed to be accountable.

Funding The authors have not declared a specific grant for this research from any funding agency in the public, commercial or not-for-profit sectors.

Competing interests None declared.

Patient consent for publication Obtained.

Provenance and peer review Not commissioned; externally peer reviewed.

\section{REFERENCES}

1 Brook I. Acute bacterial suppurative parotitis: microbiology and management. J Craniofac Surg 2003;14:37-40.

2 Amin MA, Bailey BM, Patel SR. Clinical and radiological evidence to support superficial parotidectomy as the treatment of choice for chronic parotid sialadenitis: a retrospective study. Br J Oral Maxillofac Surg 2001;39:348-52.

Copyright 2020 BMJ Publishing Group. All rights reserved. For permission to reuse any of this content visit

https://www.bmj.com/company/products-services/rights-and-licensing/permissions/

BMJ Case Report Fellows may re-use this article for personal use and teaching without any further permission.

Become a Fellow of BMJ Case Reports today and you can:

- Submit as many cases as you like

- Enjoy fast sympathetic peer review and rapid publication of accepted articles

- Access all the published articles

Re-use any of the published material for personal use and teaching without further permission

Customer Service

If you have any further queries about your subscription, please contact our customer services team on +44 (0) 2071111105 or via email at support@bmj.com.

Visit casereports.bmj.com for more articles like this and to become a Fellow 